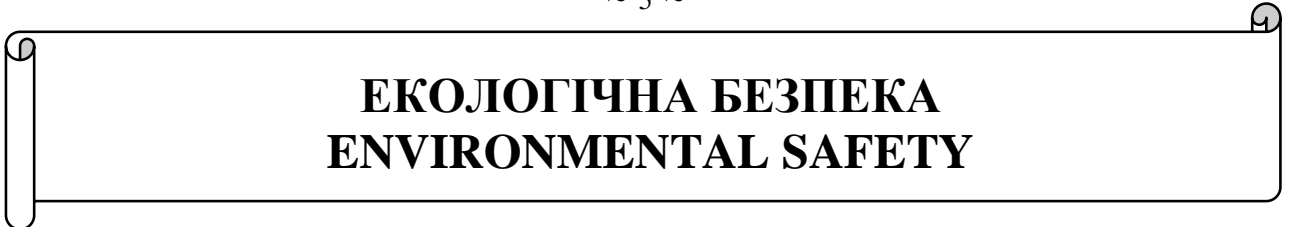

УДК 004.942

Stanislav O. Dovgiy, Member of the National Academy of Sciences of Ukraine, D. S. (Computer science), professor, Director-organizer

ORCID ID 0000-0003-1078-0162 e-mail: s.dovgii@gmail.com

Oleh V. Kopiika, D. S. (Computer science), Head of department

ORCID ID 0000-0003-0189-3915 e-mail: okopiyka@gmail.com

Institute of Telecommunications and Global Information Space of NASU, Kyiv, Ukraine

\title{
CHANGING THE BUSINESS MODEL OF IT MANAGEMENT AT ENVIRONMENTAL ENTERPRISE IN CONNECTION WITH THE DEVELOPMENT OF SERVICE-ORIENTED INFORMATION TECHNOLOGIES
}

\begin{abstract}
The article offers approaches to building a business model of IT management at an enterprise that deals with the tasks of nature management, taking into account the needs of departments in modern service-oriented information technologies. To increase the efficiency of IT implementation in the enterprise, it is proposed to use the COBIT 5 methodology, which helps companies to achieve optimal efficiency from IT implementation, maintaining a balance between receiving benefits and risks and resources optimizing. The implementation of the methodology will provide an opportunity to manage and control IT throughout the enterprise, both in the field of functional responsibility of IT and business, and also allows to take into account the IT needs of internal and external stakeholders. However, each company must build its own purpose, specifying and detailing it in accordance with the balanced performance maps (finance, customer, internal management and training and development), in addition, performed the task of effective IT implementation associated with development priorities of business. In this case, the task of approving the decision is multi-criteria. Therefore, special attention deserve issues as finding reasons of such multicriteria and the possibility of using appropriate mathematical methods for the purpose of the cascade. The next reason for the multicriteria of decision-making tasks is the influence of time and space. The concrete implementation of decision-making principles is offered in the form of algorithms or procedures for solving multicriteria optimization problems. Almost all known approaches to solving these problems involve their scalarization. Thus one of the main issues is the list of preferences of the person who makes decisions in choosing the best solution. In accordance with this principle, the methods of solving problems of multicriteria optimization will be classified according to the characteristics of the information: decision-making under conditions of certainty; decision-making in the absence of information about the system of preference of the decision-maker; decision-making in the conditions of gradual receipt of information about the system of preference of the decision-maker.
\end{abstract}

Keywords: business model; business goal; information technology (IT); IT services; IT goal; decision making with many criteria; methods of multicriteria optimization

(c) С.О. Довгий, О.В. Копійка, 2021

ISSN: 2411-4049. Екологічна безпека та природокористування, № 1 (37), 2021 


\title{
С.О. Довгий, О.В. Копійка
}

Інститут телекомунікацій і глобального інформаційного простору НАН України, м. Київ, Україна

\section{ЗМІНА БІЗНЕС-МОДЕЛІ УПРАВЛІННЯ ІТ НА ПЦДПРИЕМСТВІ ПРИРОДОКОРИСТУВАННЯ У ЗВ'ЯЗКУ 3 РОЗВИТКОМ СЕРВІСНО-ОРІСНТОВАНИХ ІНФОРМАЦІЙНИХ ТЕХНОЛОГІЙ}

\begin{abstract}
Анотація. Пропонуються підходи до побудови бізнес-моделі управління IT на підприємстві, яке займається задачами природокористування, з врахуванням задоволення потреб підрозділів в сучасних сервісно-орієнтованих інформаційних технологіях. Для підвищення ефективності впровадження IT на підприємстві пропонується використовувати методологію СОВІТ 5, яка допомагає підприємствам досягти оптимальної ефективності від впровадження IT, підтримуючи баланс між одержанням вигоди й оптимізацією ризиків $і$ ресурсів. Впровадження методології надасть можливість керувати й управляти IT у масштабах усього підприємства, як у сфері функиіональної відповідальності IT, так і бізнесу, а також дозволяє враховувати потреби в IT внутрішніх і зовнішніх зачікавлених сторін. При цьому, кожне підприємство повинно вибудовувати власну мету, уточнюючи та деталізуючи її у відповідності до збалансованої мапи показників (фінанси, замовник, внутрішне управління та навчання та розвиток), окрім иього виконується задача ефективного впровадження IT, яка пов'язана $з$ пріоритетами розвитку бізнесу. У иььому випадку завдання схвалення рімення $\epsilon$ багатокритеріальним. Тому на окрему увагу заслуговують питання пошуку причин подібної багатокритеріальності й можливості використання для каскаду мети відповідних математичних методів. Наступна причина багатокритеріальності задач прийняття рішень - ие вплив фактору часу й простору. Конкретна реалізація принципів прийняття рішень пропонується у вигляді алгоритмів або процедур розв'язку задач багатокритеріальної оптимізації. Практично всі відомі підходи до розв'язку изих завдань припускають їх скаляризацію. При иьому одним з головних питань є перелік переваг особи, яка приймає рімення, у проиесі вибору найкращого рімення. Відповідно до иього принципу методи рішення завдань багатокритеріальної оптимізації будемо класифікувати відповідно до характеристики інформації: ухвалення рішення в умовах визначеності; ухвалення рішення в умовах відсутності інформації про систему переваг особи, яка приймає рішення; ухвалення рішення в умовах поступового одержання інформаџї̈ про систему переваги особи, яка приймає рішення.
\end{abstract}

Ключові слова: бізнес-модель; бізнес-мета; інформаційні технології (IT); IT-мета; IT-послуги; прийняття рішень при багатьох критеріях; методи багатокритеріальної оптимізації

\section{Вступ}

Інформація стає все більш цінним активом бізнесу, а в багатьох випадках основним. Швидкий розвиток інформаційних технологій (IT) усунув фізичні бар'єри для виробництва й передачі інформації, змінилося наше розуміння того, яким чином інформація здобувається (виробляється) й споживається. 
Сучасний інформаційно-технологічний світ усе частіше складається 3 сервісів зберігання й передачі інформації через хмару. Тому, пропозиції SaaS від постачальників програмного забезпечення (ПЗ) стали звичайним явищем на ринку інформаційних технологій.

Існує значна кількість досліджень 3 цієї теми [1-5]. Важливим $є$ те, що еволюція управління ІТ-послугами відбувалася більш-менш синхронно 3 фундаментальними змінами в суспільстві.

Можна виділити три етапи еволюціонування мети управління IT-послугами й результатів ІТ-діяльності:

- управління IT-інфраструктурою;

- управління IT-сервісами;

- управління інформаційними бізнес-сервісами.

Більш докладно ці етапи описано в таблиці 1. Кожний з них можна, 3 певним ступенем точності, пов'язати зі зміною розуміння ролі ІТ у компанії-переходом від технологічного підрозділу до повноцінного партнерства (рис. 1).

\section{Таблиця 1 - Три етапи еволюції управління IT}

\begin{tabular}{|c|c|c|c|}
\hline Етап & Задачі & Пріоритети & Характерні риси \\
\hline Етап 1 & $\begin{array}{l}\text { Управління } \\
\text { IT-інфраструктурою }\end{array}$ & $\begin{array}{l}\text { Стабільність і } \\
\text { контроль IT- } \\
\text { інфраструктури }\end{array}$ & $\begin{array}{l}\text { • IT-департамент } \epsilon \\
\text { постачальником IT-систем; } \\
\text { • мета управління IT - мінімізація } \\
\text { переривань у роботі IT-систем. }\end{array}$ \\
\hline Етап 2 & $\begin{array}{l}\text { Управління } \\
\text { IT-сервісами }\end{array}$ & $\begin{array}{l}\text { Якість й } \\
\text { ефективність } \\
\text { IT-процесів }\end{array}$ & $\begin{array}{l}\text { • ІТ-департамент } \epsilon \\
\text { постачальником } \\
\text { технологічних сервісів; } \\
\text { • мета управління IT - підтримка } \\
\text { погоджених параметрів надання } \\
\text { IT-сервісів. }\end{array}$ \\
\hline Етап 3 & $\begin{array}{l}\text { Управління } \\
\text { інформаційними } \\
\text { бізнес-сервісами }\end{array}$ & $\begin{array}{l}\text { Максимальна } \\
\text { ефективність IT }\end{array}$ & $\begin{array}{l}\text { • ІТ-департамент } \epsilon \\
\text { постачальником інформаційних } \\
\text { бізнес-сервісів; } \\
\text { • мета управління IT - } \\
\text { максимально точна відповідність } \\
\text { потребам бізнесу. }\end{array}$ \\
\hline
\end{tabular}

Вочевидь, що завдяки підвищенню ролі й значення IT у компанії повинна відбуватися еволюція розуміння мети управління IT-послугами й результатів ІТ-діяльності [6].

Не менш вагомим $є$ те, що еволюцію в розумінні мети керування IT-послугами й результатів IT-діяльності можна асоціювати зі зрушенням у суспільній свідомості: переходом від продуктово-орієнтованої виробничої економіки до сервісно-орієнтованої інформаційної економіки (звичайно, з визначеною долею умовності, тому що зміна економічної парадигми відбувалася досить повільно й поступово).

Крім загальноринкових факторів, еволюція розуміння того, що ж $є$ результатом ІТ-діяльності, була викликана необхідністю дати основу для відповідей на складні практичні питання, що існують в області IT. 


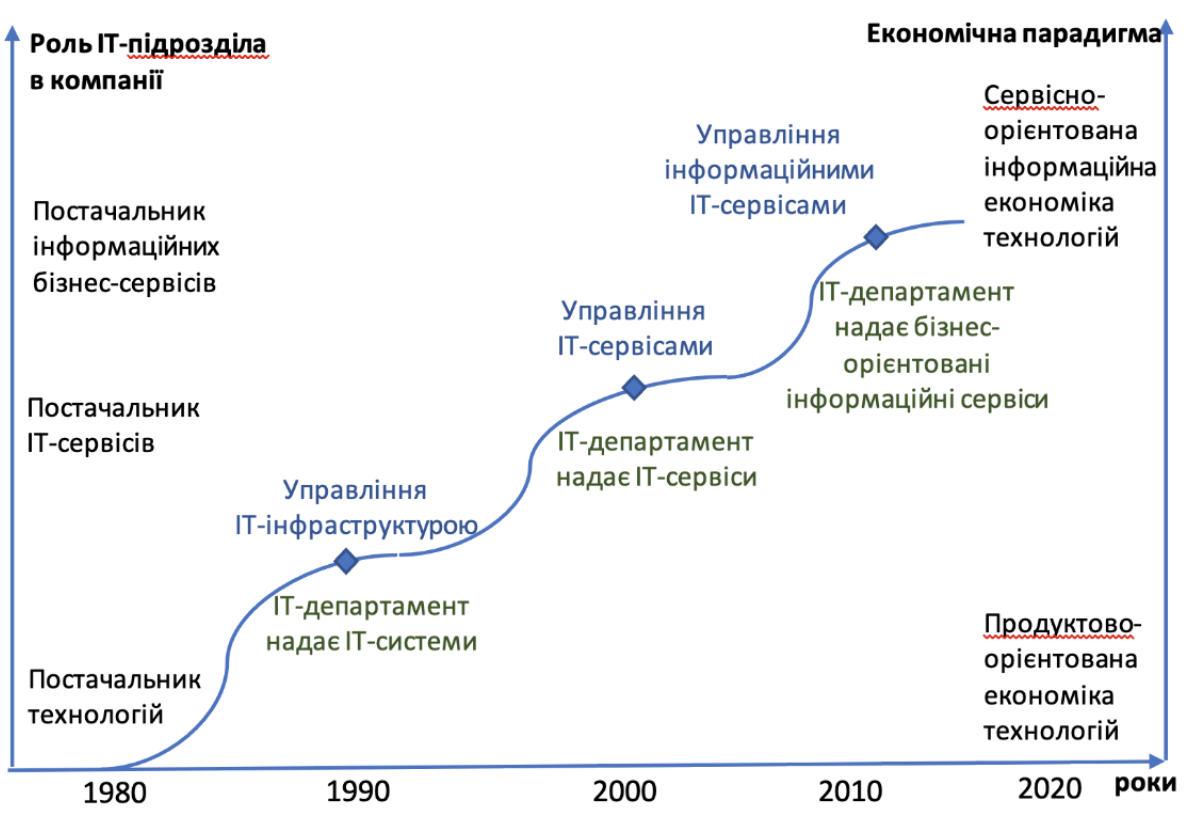

Рис. 1 - Етапи в еволюції мети управління IT-послугами й результатів IT-діяльності

IT-керівники постійно стикаються з багатьма проблемами, для вирішення яких не було системного інструменту. Серед них:

- обгрунтування постійного зростання витрат на IT;

- обгрунтування цінності, яку компанія отримує від інвестицій в IT, проблема невідповідності результатів очікуванням керівництва компанії;

- управління вимогами до IT, проблеми узгодження очікувань бізнеспідрозділів і можливостей ІТ-департаменту;

- хронічна нестача IT-ресурсів, ІТ-компетенцій і проблеми залучення зовнішніх ІТ-провайдерів для вирішення складних завдань.

Отже, метою цієї статті $\epsilon$ презентація підходів до побудови бізнес-моделі управління IT на підприємстві, яке займається задачами природокористування, 3 врахуванням задоволення потреб бізнес-підрозділів в сучасних сервісноорієнтованих інформаційних технологіях.

\section{Виклад основного матеріалу дослідження}

Безумовно, споживачеві потрібна не ІТ-система як така, а результат іï діяльності [7-9]. I одержання цього результату може вимагати й, як правило, вимагає більшої кількості активів, ніж наявність тільки лише IT-системи. Не можна задовольнити комплексні потреби бізнесу, якщо зробити центральним предметом діалогу тільки ІТ-системи. Рух уперед починається зі спільного розуміння спільної мети й завдань.

Підсумовуючи вищезазначене, необхідно зауважити, що інформація $\epsilon$ критично важливим ресурсом для всіх підприємств. На всіх етапах свого життєвого циклу інформація критичним чином залежить від спеціалізованих технологій. Інформація та інформаційні технології, які динамічно розбудовуються, є життєвоважливими для сучасних підприємств: як суспільних, державних, так і комерційних. 
Тому сьогодні, більше, ніж будь-коли, підприємства i їх керівники зобов'язані:

- Підтримувати високу якість інформації для прийняття управлінських рішень.

- Створювати цінність для бізнесу, реалізуючи інвестиції, пов'язані з IT, тобто досягати стратегічної мети й одержувати прибуток шляхом ефективного й інноваційного використання IT.

- Удосконалювати операційну модель, надійно та раціонально застосовуючи технології.

- Забезпечувати прийнятний рівень IT-ризиків.

- Оптимізувати витрати на IT-послуги й технології.

- Підвищувати ступінь дотримання законів, норм, договірних зобов'язань і політик, пов'язаних із застосуванням IT.

Таким чином, сучасними характеристиками впровадження IT є:

- управління інформаційними бізнес-сервісами;

- підвищення цінності IT;

- IT-департамент стає постачальником інформаційних бізнес-сервісів;

- мета управління IT - максимально точна відповідність потребам бізнесу.

Виходячи 3 цього, пропонуємо для підвищення ефективності впровадження IT на підприємстві використовувати методологію COBIT 5, яка покликана допомогти в розв'язанні завдання керівництва й управління IT на підприємстві [10].

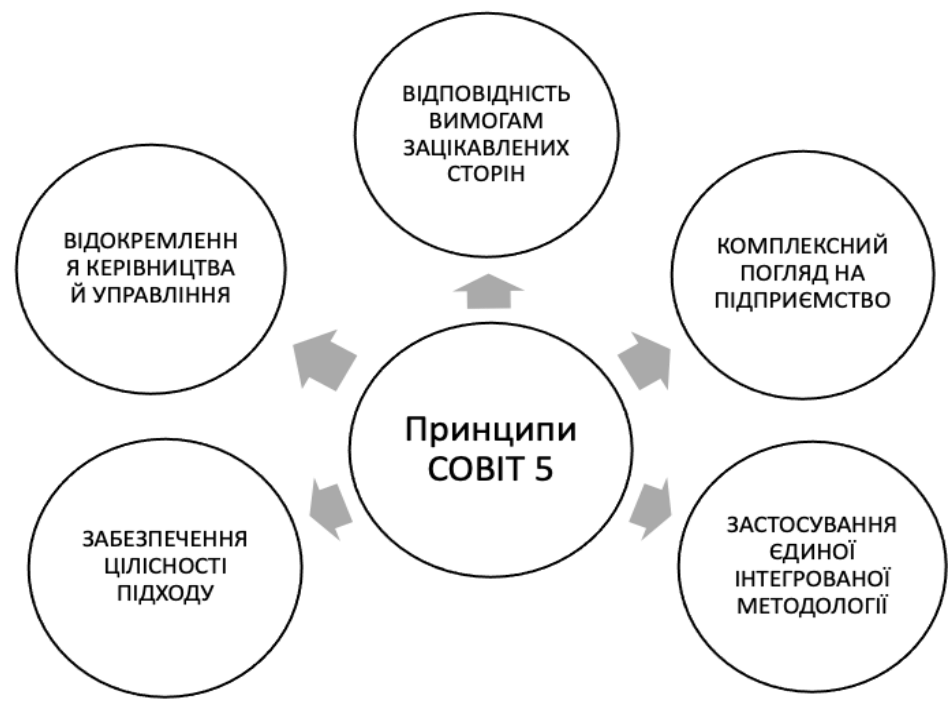

Рис. 2 - Принципи СОВIT 5

Застосування цієї методології допомагає підприємствам досягти оптимальної ефективності від впровадження IT, підтримуючи баланс між одержанням вигоди й оптимізацією ризиків i ресурсів. Впровадження методології надасть можливість керувати й управляти IT у масштабах усього підприємства, як у сфері функціональної відповідальності IT, так і бізнесу, а також дозволяє враховувати потреби в IT внутрішніх і зовнішніх зацікавлених сторін. Методологія універсальна й буде корисна підприємствам будь-якого масштабу й сфери діяльності: комерційним, суспільним і державним. 
Методика грунтується на п'ятьох принципах керівництва й управління IT на підприємстві, що зображені на рисунку 2.

Принцип 1: Відповідність вимогам зацікавлених сторін.

Підприємства існують для того, щоб створювати цінність для зацікавлених сторін, шляхом підтримки балансу між одержанням вигоди й оптимізацією ризиків і ресурсів. Методика описує всі необхідні процеси й інші фактори впливу, які підтримують створення бізнес-цінності за допомогою ІТ. Оскільки завдання, що стоять перед кожним підприємством, можуть бути різними, можна модифікувати модель так, щоб ці рекомендації підходили до конкретного контексту даної організації. Зробити це можна за допомогою каскадування високорівневих завдань підприємства до рівня керованих i конкретних IT-завдань і пов'язаних з ними процесів і практик (рис. 3).

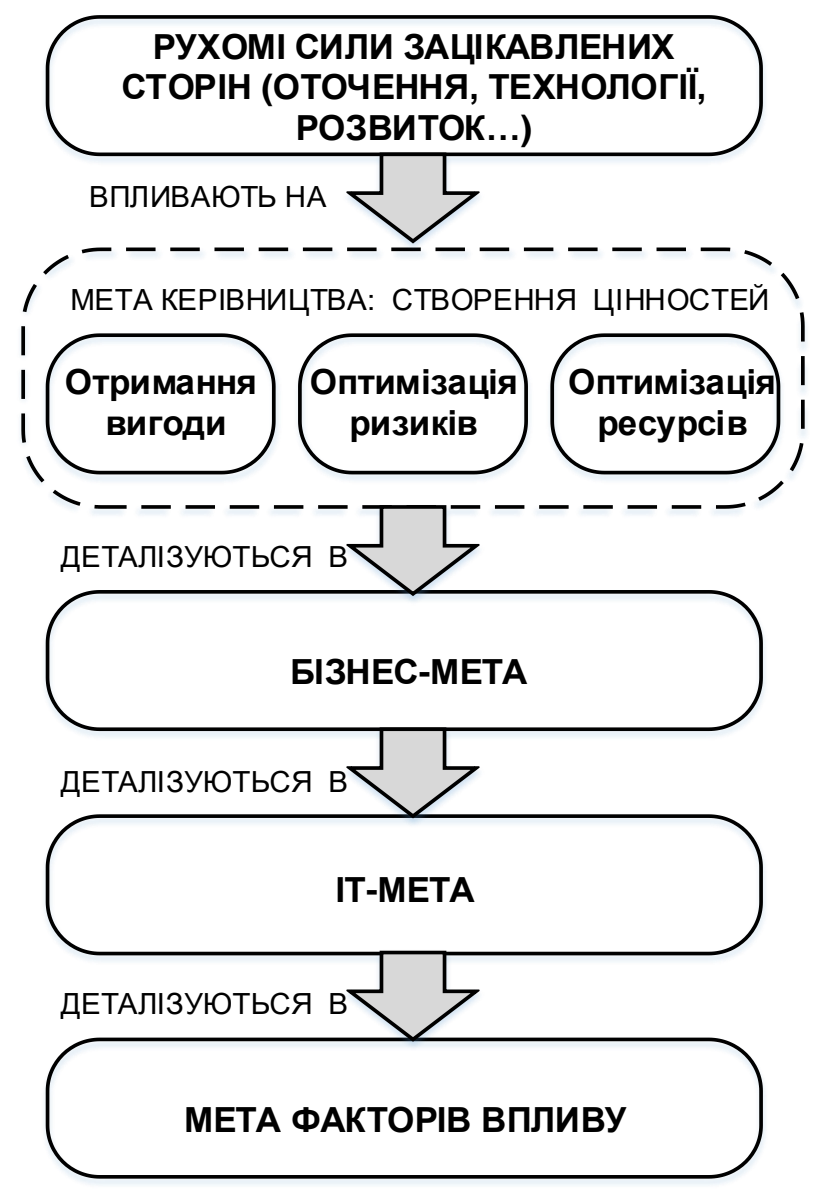

Рис. 3 - Каскад мети

\section{Принцип 2: Комплексний погляд на підприсмство.}

Методика вбудовує керівництво IT у керівництво підприємства у цілому, тобто:

- розглядає всі функції й процеси підприємства. Методика спрямована не тільки на реалізацію «ІТ-функції», а й розглядає інформацію та пов' язані з нею активи підприємства, якими слід управляти, як і будь-якими іншими активами; 
- грунтується на тому, що фактори впливу керівництва й управління, пов'язані 3 IT, працюють на всьому підприємстві й ланцюжку створення цінності і містять у собі всі внутрішні й зовнішні аспекти й ролі, які мають стосунок до керівництва й управління IT.

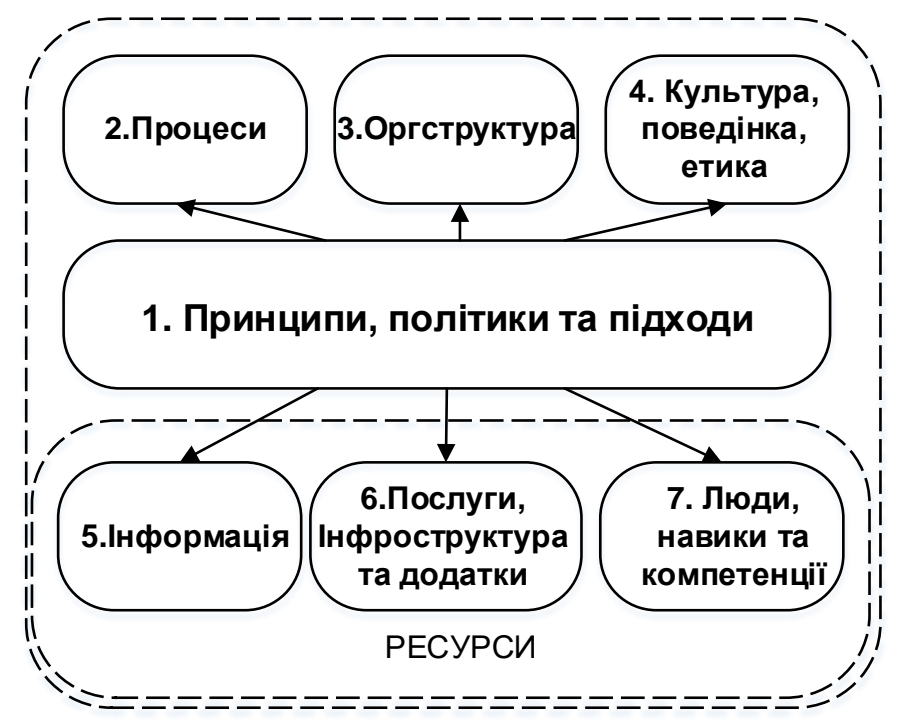

Рис. 4 - Фактори впливу

\section{Принцип 3: Застосування сдиної інтегрованої методології.}

Існує множина пов'язаних з IT стандартів, що стосуються окремих аспектів IT-діяльності. У методиці реалізована відповідність цим стандартам. Таким чином, методика забезпечує інтеграційний підхід для організації керівництва й управління IT на підприємстві.

Принцип 4: Забезпечення цілісності підходу.

Ефективне й раціональне керівництво й управління IT на підприємстві вимагає структурованого підходу з урахуванням багатьох взаємозалежних компонентів мети.

У методиці описаний набір факторів впливу, які забезпечують впровадження системи керівництва й управління IT на підприємстві. Фактори впливу - це сутності, які сприяють вирішенню завдань підприємства. Методика описує сім видів факторів впливу (рис. 4): принципи, політики й підходи; процеси; організаційна структура; культура, етика й поведінка; інформація; послуги, інфраструктура й додатки; персонал, навички й компетенції.

\section{Принцип 5: Відокремлення керівництва й управління.}

Методика проводить чітку межу між керівництвом й управлінням. Ці дві дисципліни містять у собі різні види діяльності, вимагають різних організаційних структур і служать різній меті. У розумінні методики різниця між керівництвом і управлінням полягає в наступному.

У більшості випадків обов'язки з керівництва на підприємстві виконує рада директорів, яка очолена головою ради директорів.

Деякі обов'язки можуть бути делеговані спеціальним організаційним одиницям відповідного рівня - особливо у великих організаціях. 
Значною мірою, обов'язки 3 управління на підприємстві виконують виконавчі директори, очолювані генеральним директором (CEO). Разом ці принципи допомагають побудувати ефективну методологію керівництва й управління, що оптимізує інвестиції в інформаційні технології для одержання вигоди зацікавленими сторонами.

Беручи до уваги сформульовані п'ять принципів, мета підприємства та мета впровадження IT узгоджуються наступним чином (табл. 2).

Таблиця 2 - Зв' язок мети підприємства 3 головними завданнями керівництва («Р» означає прямий зв’язок, а «S» - непрямий, тобто менш сильний)

\begin{tabular}{|c|c|c|c|c|}
\hline \multirow{2}{*}{$\begin{array}{c}\text { Вимірювання } \\
\text { збалансованої } \\
\text { мапи } \\
\text { показників }\end{array}$} & \multirow[b]{2}{*}{ Мета підприємства } & \multicolumn{3}{|c|}{$\begin{array}{c}\text { Зв'язок із завданнями } \\
\text { керівництва }\end{array}$} \\
\hline & & \begin{tabular}{|c|}
$\begin{array}{c}\text { Одержання } \\
\text { вигоди }\end{array}$ \\
\end{tabular} & \begin{tabular}{|c|} 
Оптимі- \\
зація \\
ризиків \\
\end{tabular} & \begin{tabular}{|l} 
Оптимі- \\
зація \\
ресурсів
\end{tabular} \\
\hline \multirow{5}{*}{ Фінанси } & $\begin{array}{l}\text { 1. Прибуток від інвестицій для } \\
\text { зацікавлених сторін }\end{array}$ & $\mathrm{P}$ & & $\mathrm{S}$ \\
\hline & $\begin{array}{l}\text { 2. Портфель конкурентоспроможних } \\
\text { товарів і послуг }\end{array}$ & $\mathrm{P}$ & $\mathrm{P}$ & $S$ \\
\hline & $\begin{array}{l}\text { 3. Керовані бізнес-ризики (захист } \\
\text { активів) }\end{array}$ & & $\mathrm{P}$ & $S$ \\
\hline & $\begin{array}{l}\text { 4. Відповідність зовнішнім законам } \\
\text { і регулюючим нормам }\end{array}$ & & $\mathrm{P}$ & \\
\hline & 5. Фінансова прозорість & $\mathrm{P}$ & $\mathrm{S}$ & $\mathrm{S}$ \\
\hline \multirow{5}{*}{ Замовник } & $\begin{array}{l}\text { 6. Сервісна культура орієнтована } \\
\text { на клієнта }\end{array}$ & $\mathrm{P}$ & & $S$ \\
\hline & $\begin{array}{l}\text { 7. Безперервність і доступність } \\
\text { бізнес-послуг }\end{array}$ & & $\mathrm{P}$ & \\
\hline & $\begin{array}{l}\text { 8. Гнучка реакція на мінливі умови } \\
\text { ведення бізнесу }\end{array}$ & $\mathrm{P}$ & & $S$ \\
\hline & $\begin{array}{l}\text { 9. Прийняття стратегічних рішень } \\
\text { на основі інформації }\end{array}$ & $\mathrm{P}$ & $\mathrm{P}$ & $\mathrm{P}$ \\
\hline & $\begin{array}{l}\text { 10. Оптимізація витрат на надання } \\
\text { послуг }\end{array}$ & $\mathrm{P}$ & & $\mathrm{P}$ \\
\hline \multirow{5}{*}{$\begin{array}{l}\text { Внутрішнє } \\
\text { управління }\end{array}$} & $\begin{array}{l}\text { 11. Оптимізація функціональності } \\
\text { бізнес-процесів }\end{array}$ & $\mathrm{P}$ & & $\mathrm{P}$ \\
\hline & $\begin{array}{l}\text { 12. Оптимізація витрат бізнес- } \\
\text { процесів }\end{array}$ & $\mathrm{P}$ & & $\mathrm{P}$ \\
\hline & $\begin{array}{l}\text { 13. Керування програмами бізнес- } \\
\text { змін }\end{array}$ & $\mathrm{P}$ & $\mathrm{P}$ & $\mathrm{S}$ \\
\hline & $\begin{array}{l}\text { 14. Операційна продуктивність } \\
\text { персоналу }\end{array}$ & $\mathrm{P}$ & & $P$ \\
\hline & 15. Дотримання внутрішніх політик & & $\mathrm{P}$ & \\
\hline \multirow{2}{*}{$\begin{array}{l}\text { Навчання } \\
\text { та } \\
\text { розвиток }\end{array}$} & $\begin{array}{l}\text { 16. Кваліфікований і мотивований } \\
\text { персонал }\end{array}$ & $\mathrm{S}$ & $\mathrm{P}$ & $P$ \\
\hline & $\begin{array}{l}\text { 17. Культура довгострокових } \\
\text { інновацій продуктів та бізнесу }\end{array}$ & $\mathrm{P}$ & & \\
\hline
\end{tabular}


Важливість цієї мети полягає в тому, що вона дозволяє визначити пріоритети впровадження, удосконалення й гарантує наявність керівництва IT на підприємстві на основі розуміння (стратегічної) мети підприємства, а також зв'язаних ризиків. На практиці ця мета:

- визначає важливі й обгрунтовані цілі й завдання на різних рівнях відповідальності;

- дозволяє витягти з бази знань усі дані про визначені цілі підприємства, які можуть знадобитися в проектах впровадження, удосконалення або оцінки якості;

- ясно визначає і демонструє (у деяких випадках дуже докладно) те, яким чином фактори впливу допомагають у досягненні мети підприємства.

Таблиця відповідності між метою підприємства й IT-цілями (табл. 3) не є безперечною істиною в останній інстанції, і потрібно використовувати іiі не буквально, а як підказку.

\section{Таблиця 3 - Цілі IT}

\begin{tabular}{|c|c|}
\hline $\begin{array}{l}\text { Вимірювання } \\
\text { збалансованої } \\
\text { мапи } \\
\text { показників }\end{array}$ & Мета інформаційних і пов'язаних з інформацією технологій \\
\hline \multirow{6}{*}{ Фінанси } & 1. Відповідність між ІТ- і бізнес-стратегіями \\
\hline & $\begin{array}{l}\text { 2. Відповідність зовнішньому законодавству та регулюючим } \\
\text { вимогам в галузі ІT та підтримка бізнес-відповідності }\end{array}$ \\
\hline & $\begin{array}{l}\text { 3. Лідируюча роль вищого керівництва в прийнятті рішень в } \\
\text { області IT }\end{array}$ \\
\hline & 4. Керовані бізнес-ризики, пов'язані з використанням IT \\
\hline & 5. Реалізація прибутку від портфеля IT інвестицій і послуг \\
\hline & 6. Прозорість ІТ-витрат, вигід і ризиків \\
\hline \multirow{2}{*}{ Замовник } & 7. Надання IT-послуг у відповідь на бізнес-вимоги \\
\hline & 8. Адекватне використання додатків, інформації й технічних рішень \\
\hline \multirow{7}{*}{$\begin{array}{l}\text { Внутрішнє } \\
\text { управління }\end{array}$} & 9. Гнучкість IT \\
\hline & 10. Безпека інформації, що обробляє інфраструктури й додатки \\
\hline & 11. Оптимізація IT-активів, ресурсів і здатностей \\
\hline & $\begin{array}{l}\text { 12. Забезпечення роботи й підтримка бізнес-процесів, шляхом } \\
\text { інтеграції додатків і технологій у бізнес-процеси }\end{array}$ \\
\hline & $\begin{array}{l}\text { 13. Здобуття вигоди з програм і проектів, що виконуються у } \\
\text { визначені терміни, бюджет та відповідність вимогам і } \\
\text { стандартам якості }\end{array}$ \\
\hline & $\begin{array}{l}\text { 14. Доступність надійної та потрібної інформації для прийняття } \\
\text { рішень }\end{array}$ \\
\hline & 15. Дотримання внутрішніх політик \\
\hline \multirow[b]{2}{*}{$\begin{array}{l}\text { Навчання та } \\
\text { розвиток }\end{array}$} & 16. Компетентний і мотивований персонал IT \\
\hline & $\begin{array}{l}\text { 17. Знання, експертиза й ініціативність для здійснення бізнес- } \\
\text { інновацій }\end{array}$ \\
\hline
\end{tabular}

Отже, кожне підприємство повинно вибудовувати власну мету, уточнюючи та деталізуючи їі у відповідності до збалансованої мапи показників (фінанси, замовник, внутрішне управління та навчання та розвиток), окрім цього, виконується задача ефективного впровадження IT, яка пов'язана 3 пріоритетами розвитку бізнесу. 
У цьому випадку завдання схвалення рішення є багатокритеріальним. Тому на окрему увагу заслуговують питання пошуку причин подібної багатокритеріальності й можливості використання для каскаду мети відповідних математичних методів.

Таким чином, мета «Впровадження IT» зводиться до встановлення значень більшого числа якісних і кількісних параметрів - часткових цілей. Ці цілі можуть конкурувати між собою.

Наступна причина багатокритеріальності задач прийняття рішень - вплив фактору часу - простору. І результати діяльності, і витрати розподілені, тому доводиться порівнювати «цінність» впровадження IT сьогодні, завтра й через рік, перспективи розвитку і т.п. Відомі прийоми згортки (наприклад, для розподілу в часі - дисконтування) несуть у собі неабияку частку суб'єктивізму (причому суб'єктивізму автора методики, а не експерта - особи, що приймає рішення (ОПР)).

Постановка задач прийняття рішень при багатьох критеріях принципово пов'язана із двома аспектами. 3 одного боку, ці задачі близькі до задач прийняття рішень в умовах невизначеності, тому що різні варіанти рішень повинні оцінюватися також і відносно ймовірності їх успіху й пов'язаного із цим ризику. 3 іншого боку, у багатокритеріальних задачах прийняття рішень в умовах визначеності урахування великої кількості критеріїв засноване на відмові від традиційного допущення того, що вибір однієї з альтернатив завжди здійснюється на підгрунті лише одного критерію. У таких ситуаціях скалярне завдання оптимізації замінюється завданням векторної оптимізації.

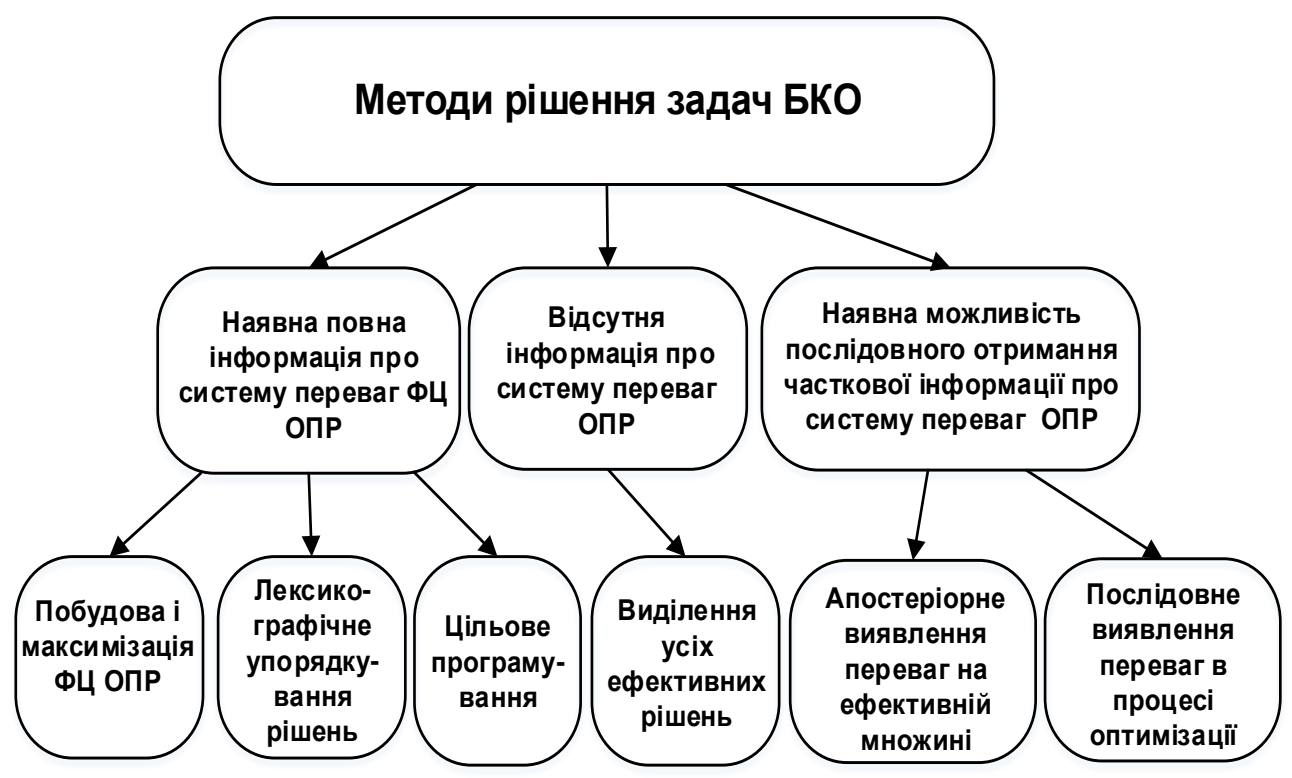

Рис. 5 - Класифікація методів рішення багатокритеріальних задач

Прагнення урахування цих двох аспектів вимагало розробки математичної моделі, яка відображала б багатомірну систему цільових функцій у скалярний критерій оптимальності. Такий підхід вимагає допущення в особи, що приймає рішення, наявності спеціальних функцій переваги. Справедливість цього 
припущення заздалегідь не очевидна. Однак цей напрямок має досить розвинену теорію розв'язків таких завдань [11-15].

Конкретна реалізація принципів прийняття рішень виступає у вигляді алгоритмів або процедур розв'язку задач багатокритеріальної оптимізації (БКО). Практично всі відомі підходи до розв'язку цих завдань припускають їх скаляризацію. При цьому одним з головних питань $є$ врахування переваг ОПР у процесі вибору найкращого рішення. Відповідно до цього принципу методи вирішення завдань багатокритеріальної оптимізації можна класифікувати відповідно до характеристики інформації про переваги ОПР:

$\checkmark$ ухвалення рішення в умовах визначеності;

$\checkmark$ ухвалення рішення в умовах відсутності інформації про систему переваги ОПР;

$\checkmark$ ухвалення рішення в умовах поступового одержання інформації про систему переваги ОПР.

Класифікація багатокритеріальних методів прийняття рішень наведена на рис. 5.

Розглянемо першу групу завдань, пов'язаних 3 ситуацією визначеності, щодо системи переваги ОПР [16].

1. Особливо великий клас принципів прийняття рішення грунтується на існуванні на безлічі векторних оцінок відносини переваги, залежить тільки від системи цільових функцій. В цьому випадку можлива побудова відповідної функції цінності. Крім цього, знання функції цінності однозначно визначає структуру переваги ОПР. Більш детальну інформацію про теорію функції цінності можна знайти в [17].

2. Одним з методів прийняття рішень в багатокритеріальній оптимізації для звуження паретовської безлічі $\epsilon$ поняття упорядкування критеріїв за важливістю. Питання про важливість критеріїв, адресовані ОПР, виявляються, 3 одного боку, досить зрозумілими ОПР, а з іншого - iї поради можуть бути ефективно використані в алгоритмах оптимізації. Однак, у багатьох методах потрібно, щоб важливість критеріїв ОПР висловила точно (повідомила вагові коефіцієнти). Прикладом якісного упорядкування критеріїв (без визначення вагових коефіцієнтів) є лексикографічне впорядкування, а багатокритеріальні задачі зі строго ранжируваними за важливістю критеріями називаються лексикографічними завданнями оптимізації. Ясно, що коло багатокритеріальних задач 3 лексикографічним упорядкуванням занадто вузьке. Принцип лексикографічного впорядкування може використовуватися і у випадках, коли на критеріальному просторі задаються порогові (мінімально допустимі) значення критеріїв. Тоді вказане впорядкування вихідних критеріїв за важливістю буде визначатися черговістю максимізації цих критеріїв до відповідних порогових значень і багатокритеріальна задача перетворюється в лексикографічне завдання з векторним критерієм. Однак, слід зазначити, що в загальному випадку лексикографічного завдання оптимізація може виявитися нестійкою, оскільки незначні зміни параметрів (вихідних даних), що входять до неї, можуть серйозно позначитися на виборі оптимальних альтернатив. Тому для їх вирішення застосовуються спеціальні методи.

3. Ще одним алгоритмом прийняття рішень в умовах визначеності є методи цільового програмування. В основі методу цільового програмування для розв'язання багатокритеріальних задач лежить впорядкування критеріїв (цілей) за ступенем важливості. Вихідна задача вирішується шляхом 
послідовного вирішення ряду завдань 3 однією цільовою функцією таким чином, що рішення задачі 3 менш важливою метою не може погіршити оптимального значення цільової функції 3 більш високим пріоритетом. В результаті ми отримуємо задовільне рішення для даної проблеми. Цільове програмування, як правило, застосовується до лінійних моделей. Основна його відмінність від завдання лінійного програмування полягає в тому, що багато цілей формалізуються не як цільові функції, а як обмеження в іншій, більш загальній моделі. 3 цією метою вводяться передбачувані кількісні значення цільових функцій і так звані змінні відхилення, які характеризують ступінь досягнення поставлених цілей для даного рішення.

У разі, коли немає ніякої інформації про систему переваг ОПР, застосовуються стандартні процедури виявлення ефективних рішень. Потім ОПР вибирає найкращу альтернативу, шляхом явного оцінювання.

Для випадку поступового отримання часткової інформації про систему переваг ОПР є дві групи багатокритеріальних методів прийняття рішень.

1. Приклад методу багатокритеріальної оптимізації, що відноситься до групи, позначеної нами на класифікаційній схемі як «апостеріорне виявлення переваг на ефективній множині». В цьому випадку застосовуються так звані методи ЕЛЕКТРА, запропоновані відомим фахівцем з ТПР професором Б. Руа (Франція) [18].

Мета застосування методів ЕЛЕКТРА - звуження паретовської множини альтернатив. Робиться це так. Для кожного з критеріїв (передбачається, що вони - числові) визначається за результатами опитування ОПР «вага» - число, що характеризує важливість відповідного критерію. У всіх модифікаціях методу ЕЛЕКТРА робиться спроба отримання від ОПР інформації якісного характеру про відносну важливість критеріїв (вислови на кшталт «критерії 3 і 4 мають однакову важливість і мають більшу важливість, ніж критерій 1») i перетворення їі в кількісну, числову. Проблема тут полягає в тому, що зробити це можна в загальному випадку безліччю способів.

2. Інтерактивні або людино-машинні процедури вирішення завдань БКО (ЧМП). ЧМП дозволяють досліджувати області допустимих значень 3 метою пошуку в них найкращого рішення. Пошук рішення здійснюється в діалозі ОПР і системи підтримки прийняття рішень (СППР). В якості вихідних даних для ЧМП виступають варіанти рішень і критерії, за якими будуть оцінюватися ці рішення. ЧМП включають дві фази: фазу аналізу, яку проводить ОПР, і фазу розрахунків, які виконуються на комп'ютері.

1. Фаза розрахунків. СППР:

- проводить розрахунки, засновані на попередній інформації або інформації, отриманій від ОПР на попередньому кроці;

- обчислює рішення;

- виробляє допоміжну інформацію для ОПР.

2. Фаза аналізу. ОПР:

- оцінює пред'явлене рішення, визначає, чи $\epsilon$ воно (одне 3 них) прийнятним. Якщо так, то ЧМП закінчена; інакше ОПР аналізує допоміжну інформацію;

- повідомляє СППР додаткову інформацію, за допомогою якої СППР обчислює нове рішення. 


\section{Висновки}

1. Запропоновані підходи до побудови бізнес-моделі управління IT на підприємстві, яке займається задачами природокористування, 3 врахуванням задоволення потреб бізнес-підрозділів в сучасних сервісно-орієнтованих інформаційних технологіях.

2. Запропоновано використовувати методи рішення завдань багатокритеріальної оптимізації як математичного апарату для встановлення значень більшого числа якісних і кількісних параметрів - часткових цілей, що конкурують між собою. Оскільки кожне підприємство вибудовує власну мету, яка з часом змінюється та потребує деталізації.

\section{СПИСОК ЛІТЕРАТУРИ}

1. Перспективи розвитку ринку хмарних обчислень в Україні: переваги та ризики. Аналітична записка. Національний інститут стратегічних досліджень. [Електронний pecypc]. - Режим доступу: http://www.niss.gov.ua/articles/1191/. - Назва з екрана.

2. Бізнес-моделі SaaS та PaaS. Особливості реалізації та законодавчого регулювання в Україні [Електронний ресурс]. - Режим доступу: http://plp.kiev.ua/ua/publications/170business-models-saas-paas. - Назва з екрана.

3. А. В. Голидьбіна, Н. В. Язвінська Особливості сучасного ринку ІТ-послуг та специфіка просування на ньому [Електронний ресурс]. - Режим доступу: http://ev.fmm.kpi.ua/article/view/108738. - Назва з екрана.

4. Копійка О. В. Архітектура мережі в сучасних дата-центрах / О. В. Копійка // Наукові записки Українського науково-дослідного інституту зв'язку. - 2014. No 2(30). - C. 34-41.

5. Копейка О. В. Сетевые службы и службы сетевых устройств в Дата-центрах / О. В. Копейка // Системи управління, навігації та зв'язку. - 2013. - Випуск 4 (28). C. $98-104$.

6. Информационные сервисы в XXI [Електронний ресурс]. - Режим доступу: http://itclubvologda.ru/sites/default/files/news/attachment/information_services_xxi_inform ation_management_3_2013.pdf - Назва $з$ екрана.

7. Новые технологии в телекоммуникации: выбор технологической архитектуры. Современные тенденции развития / С.А. Довгий, О.В. Копейка, С.П. Поленок. - К.: Укртелеком, 2001. - $281 \mathrm{c.}$

8. Довгий С.О., Копійка О.В. Автоматизована система для підтримки прийняття рішень при ліквідації наслідків аварії на ЧАЕС // Інформатизація аерокосмічного землезнавства. - К.: Наук. думка, 2001. - С. 211-266.

9. Балашов В.А., Копийка О.В., Ляховецкий Л.M. VDSL - ближайшее будущее цифрового абонентского доступа // Зв'язок. - 2005. - № 4. - С. 10-16.

10. COBIT 5: Бизнес-модель по руководству и управлению ИТ на предприятии [Електронний ресурс]. - Режим доступу: http://www.isaca.org/cobit/pages/default.aspx 11. Волошин, О. Ф. Моделі та методи прийняття рішень : навч. посіб. для студ. вищ. навч. закл. / О. Ф. Волошин, С. О. Мащенко. - 2-ге вид., перероб. та допов. - К. : Видавничо-поліграфічний центр "Київський університет", 2010. - 336 с.

12. Экономико-математические методы и прикладные модели: Учеб. пособие для вузов / В.В. Федосеев, А.Н. Гармаш, Д.М. Дайитбегов и др.; Под ред. В.В. Федосеева. М.: ЮНИТИ, 1999. - 391 с.

13. Лотов А.В., Поспелова И.И. Многокритериальные задачи принятия решений: Учебное пособие. - М.: МАКС Пресс, 2008. - 197 с.

14. Васильев Ф. П. Методы оптимизации - М.: Факториал Пресс, 2002. - 415 с. 
15.Беркман Л. Н. Теоретичні основи методології синтезу інформаційнокомунікаційних систем / Л. Н. Беркман, О. В. Копійка // Телекомунікаційні та інформаційні технології. - 2014. - №4. - С. 12-20.

16. Соболь И.М. Выбор оптимальных параметров в задачах со многими критериями. М.: Дрофа, 2006. - 175 с. - ISBN 5-7107-7989-X.

17. Rubinstein A. Lecture Notes in Microeconomic Theory. - 2nd. - Princeton University Press, 2013. - 153 c. - ISBN 978-0-691-15413-8.

18. Руа Б. Проблемы и методы принятия решений в задачах со многими целевыми функциями // Вопросы анализа и процедуры принятия решений. М.: Мир, 1976. - 232 с.

Стаття надійшла до редакиії 10.11.2020 і прийнята до друку після рещензування 18.02.2021

\section{REFERENCES}

1. Prospects for the development of the cloud computing market in Ukraine: advantages and risks. Analytical note. National Institute for Strategic Studies. Retrieved from: http://www.niss.gov.ua/articles/1191/.

2. SaaS and PaaS business models. Peculiarities of implementation and legislative regulation in Ukraine. Retrieved from: http://plp.kiev.ua/ua/publications/170-businessmodels-saas-paas.

3. Golidbina, A.V., \& Yazvinska, N.V. Features of the modern market of IT services and the specifics of promotion on it. Retrieved from: http://ev.fmm.kpi.ua/article/view/108738 (in Ukrainian).

4. Kopiika, O.V. (2014). Network architecture in modern data centers. Scientific notes of the Ukrainian Research Institute of Communications, 2(30), 34-41 (in Ukrainian).

5. Kopiika, O.V. (2013). Network services and network device services in Data Centers. Control, navigation and communication systems, 4 (28), 98-104 (in Russian).

6. Information services in XXI. Retrieved from: http://itclubvologda.ru/sites/default/files/news/attachment/information_services_xxi_inform ation_management_3_2013.pdf

7. Dovgiy, S.O., Kopiika, O.V., \& Polenok, S.P. (2001). Novye tehnologii $v$ telekommunikacii: vybor tehnologicheskoj arhitektury. Sovremennye tendencii razvitija [New technologies in telecommunications: the choice of technological architecture. Modern development trends]. Kyiv: Ukrtelecom (in Russian).

8. Dovgiy, S.O., \& Kopiika, O.V. (2001). Avtomatyzovana systema dlia pidtrymky pryiniattia rishen pry likvvidatsii naslidkiv avarii na ChAES [Automated system to support decision-making in the aftermath of the Chernobyl accident]. In Informatyzatsiia aerokosmichnoho zemleznavstva [Informatization of aerospace geology], (pp. 211-266). Kyiv: Naukova dumka (in Ukrainian).

9. Balashov, V.A., Kopiika, O.V., \& Lyakhovetsky, L.M. (2005). VDSL - near future of digital subscriber access. Communication, 4, 10-16 (in Russian).

10. COBIT 5: Business model for the leadership and management of IT at the enterprise. Retrieved from: http://www.isaca.org/cobit/pages/default.aspx

11. Voloshin, O.F., \& Mashchenko, S.O. (2010). Modeli ta metody pryiniattia rishen [Models and methods of decision making]. (2nd ed., rev.). Kyiv: Vydavnycho-polihrafichnyi tsentr "Kyivskyi universytet" (in Ukrainian).

12. Fedoseev, V.V., Garmash, A.N., Dayitbegov, D.M. et al. (1999). Jekonomikomatematicheskie metody $i$ prikladnye modeli [Economic and mathematical methods and applied models]. (V.V. Fedoseev, Ed.). Moscow: UNITY (in Russian).

13. Lotov, A.V., \& Pospelova, I.I. (2008). Mnogokriterial'nye zadachi prinjatija reshenij [Multicriteria decision-making tasks]. Moscow: MAKS press (in Russian). 
14. Vasiliev, F.P. (2002). Metody optimizacii [Optimization methods]. Moscow: Factorial press (in Russian).

15. Berkman, L.N., \& Kopiika, O.V. (2014). Theoretical bases of methodology of synthesis of information and communication systems. Telecommunication and information technologies, 4, 12-20 (in Ukrainian).

16. Sobol, I.M. (2006). Vybor optimal'nyh parametrov $v$ zadachah so mnogimi kriterijami [Selection of optimal parameters in problems with many criteria]. Moscow: Drofa.

17. Rubinstein, A. (2013). Lecture Notes in Microeconomic Theory. (2nd ed.). Princeton University Press.

18. Rua, B. (1976). Problemy i metody prinjatija reshenij v zadachah so mnogimi celevymi funkcijami [Problems and methods of decision making in problems with many objective functions]. In Voprosy analiza i procedury prinjatija reshenij [Questions of analysis and decision making procedures]. Moscow: Mir (in Russian).

The article was received 10.11.2020 and was accepted after revision 18.02.2021

\section{Довгий Станіслав Олексійович}

академік НАН України, доктор технічних наук, професор, директор-організатор Інституту телекомунікацій і глобального інформаційного простору НАН України

Адреса робоча: 03186, м. Київ, Чоколівський бульвар, 13

ORCID ID 0000-0003-1078-0162 e-mail: s.dovgii@gmail.com

\section{Копійка Олег Валентинович}

доктор технічних наук, старший науковий співробітник, завідувач відділу Інституту телекомунікацій і глобального інформаційного простору НАН України

Адреса робоча: 03186, м. Київ, Чоколівський бульвар, 13

ORCID ID 0000-0003-0189-3915 e-mail: okopiyka@gmail.com 